\title{
The contribution of teaching practices and pupils' initial knowledge to literacy learning ${ }^{1}$
}

\author{
Carmen Buisán, Isabel Rios and Liliana Tolchinsky
}

The learning of written language results from a shared contribution of the literacy knowledge pupils bring and the pedagogical instruction they receive. The aims of the present study were (1) to assess children's emerging literacy knowledge, in terms of both notational and textual aspects, at the beginning of the third year of preschool education; (2) to obtain a detailed picture of teaching practices in initial instruction of written language in nine regions of Spain; and (3) to determine the relationship between these two factors and learning outcomes at the end of the first year of primary education. In spite of having identified three clearly different profiles of teaching practices, results indicate that children's performance in written language was more strongly associated with their initial literacy level of knowledge than with what the teacher did.

A detailed observation of classroom interactions in the context of specific tasks not only enabled us to look more closely at different learning trajectories but also revealed several socio-affective and attitudinal aspects that appear to explain the differences in learning processes.

\section{Introduction}

The term 'literacy' has taken on a broader sense than its etymological meaning: it no longer entails just the ability to read and write, but 'has instead come to be considered synonymous with its hoped-for consequences' (Aronoff, 1994, p. 68). Hence, literacy is now associated with a wide range of meanings and implications, from basic reading and writing skills to the acquisition and manipulation of knowledge via written texts, from metalinguistic analysis of grammatical units to the structure of oral and written texts, and from the impact of print on the history of mankind to the philosophical and social consequences of western education (Chafe \& Danielewicz, 1987; Goody \& Watt, 1963; Olson, 1991; Ong, 1992). 
Changes in the notion of literacy have, in turn, shifted the way in which the factors involved in its acquisition are conceptualised. Instead of searching for the best method of teaching children to read and write, researchers and educationalists now focus their attention on discovering the optimum conditions for fostering literacy practices. Some studies have looked at the role of early family experiences in relation to learning (Baker, Scher \& Mackler, 1997; Bus, van Ijzendoorn \& Pellegrini, 1995; Jong \& Leseman, 2001; Lahire, 1995), while others suggest that the key lies in there being a consistent relationship between the family, the immediate community and family practices (Brice-Heath, 1983; Zavala, Niño-Murcia \& Ames, 2004).

The bulk of research from the perspective of psychology and psycholinguistics has examined the role of the personal characteristics, skills and capacities of learners to facilitate and predict successful literacy learning (e.g., CardosoMartins, 2001; Chall, 1967; Coltheart, 1985; Coltheart, Curtis, Atkins \& Haller, 1993; Defior \& Alegría, 2005; Ellis, 1982; Linklater, O’Connor \& Palardy, 2009; McBride-Chang, 1999; Patterson \& Morton, 1985; Pennington \& Lefly, 2001; Riley, 1996; Seymour \& Evans, 1994; Wagner, Torgesen, Laughon, Simmons \& Rashotte, 1993). There is, however an increasing conviction that these studies provide a partial picture of the learning process and that it is important to consider the role of a range of teaching practices to the different amounts of prior knowledge that children bring to the classroom (Connor, Morrison \& Katch, 2004).

Another line of research has attempted to determine the influence of teaching practices on literacy learning. Focusing on methodology, some authors have studied a highly controlled teaching practice in order to evaluate its specific effects on initial literacy learning (see, among others, Aram \& Besser, 2009; Clemente \& Domínguez, 1999; Craig, 2006), while others have examined the effects of standard practices, where 'standard' may be defined either by teachers themselves or on the basis of classroom observation (for example, Castells, 2006; Connelly, Johnston \& Thompson, 2001; Hoefflin, Cusinay, Pini, Rouèche \& Gombert, 2007). Still others have observed good outcomes in reading and writing, before seeking to determine the nature of the practices that had been the most effective in promoting these outcomes (see Pressley et al., 2001). The evidence about the influence of teaching practices on children's learning should be interpreted with caution since the studies in question tend to be partial in scope (Barrio, 2006) and their findings are contradictory. Some studies have suggested that children who are exposed to synthetic approaches develop the ability to decode at an earlier stage, and are better readers, as compared with those who have been taught using analytic approaches (Artiles, 1997; Connelly et al., 2001; Jiménez \& Guzmán, 2003). Castells (2006), however, highlights the value of combining the two approaches for producing independent readers and 
Hoefflin et al. (2007) reject the idea that instructional methods affect children's literacy learning, as they failed to observe any significant differences in outcomes.

Few studies have examined the relative contribution of the teaching practices and the prior knowledge of learners to the learning outcomes. Research has looked at classroom interactions and written language learning (McKeown \& Beck, 2006; Morani \& Pontecorvo, 1995; Pascucci, 1995; Pentimonti \& Justice, 2010; Ribera, 2002; Ríos, 1999; Teberosky, 1992), but without providing a combined analysis of whether children's knowledge is associated with different teaching practices, or how teachers and learners interact when engaged in tasks designed to teach reading and writing within the framework of different 'ways of doing things'.

From a socio-constructivist perspective on teaching and learning (for a review see Palinscar, 1998), the one taken in the present study, learning is an active contextualized process of knowledge construction in which new information is linked to prior knowledge. Since learning occurs in particular social context and there is a constant interdependence of contextual and individual processes, no understanding of the learning process can be achieved by focusing either on the learner or on the teacher. That is why the present study focuses on the institutional locus of learning, i.e. the classroom, and on two of its principal agents: the learner and the teacher. We assume that the institutional process by which children make literacy practices their own can only be understood in the light of these two factors within the classroom context. The aim was to determine the contribution of each of these agents them (learners' initial knowledge and teachers' practices) to the achievement of certain learning outcomes. An additional goal was to identify differential characteristics of the interactions and strategies used by children in the classroom setting which may explain the progress or delay shown by some pupils when learning to read and write. To attain these goals it was necessary to narrow the scope of three constructs of the study: (1) the definition of literacy learning outcome, (2) of learners' initial literacy knowledge and (3) of teaching practices.

1. Among the numerous and varied features of the notion of literacy we focused on certain basic skills, on a limited set of learning targets which schools consider to be essential in order to assess reading and writing performance.

2. From among the enormous range of learner competencies, which result from the wide diversity of personal characteristics, knowledge and skills, that could have an influence on the learning targets, we selected only a few that previous research showed to be crucial in terms of learning to read and write. 
3. Among the numerous elements that form part of the everyday educational environment we decided to focus on how teachers approach the instruction of reading and writing. In order to define and explain teaching practices we identified four domains of practice, referred to as thematic blocks, which cover the multiple 'ways of doings things' and about which teachers had to express their preferences.

\section{Description of the study}

In order to determine the interaction between pupils' prior knowledge, teaching practices and successful learning of reading and writing we designed a longitudinal study to be carried out in two phases. Phase I involved defining the variable teaching practices, while Phase II centred on characterising learning processes and outcomes with respect to written language in the third year of preschool education (P-5) and the first year of primary school, these being years which are decisive for teaching literacy in the school setting. Comparative analysis of the results from the two phases enabled the most suitable practices to be identified. The design combined techniques for obtaining large amounts of data, from quantitative sources, with others that allowed for a more qualitative approach (see Table 1).

Table 1: Research design, objectives and study sample

\begin{tabular}{|c|c|c|}
\hline $\begin{array}{l}\text { PHASE I } \\
\text { July } 2006 \text { - July } 2007\end{array}$ & \multicolumn{2}{|l|}{$\begin{array}{l}\text { PHASE II } \\
\text { September } 2007 \text { - July } 2009\end{array}$} \\
\hline \multirow{5}{*}{$\begin{array}{l}\text { Objective } 1 \\
\text { Detection of teaching } \\
\text { practices } \\
\text { Sample of } 2250 \\
\text { teachers }\end{array}$} & \multicolumn{2}{|c|}{$\begin{array}{l}\text { Objective } 2 \\
\text { Characterisation of learning processes and outcomes with respect to learning how } \\
\text { to read and write }\end{array}$} \\
\hline & $\begin{array}{l}\text { Third year of preschool (age 5) } \\
\text { School year: } 2007-2008\end{array}$ & $\begin{array}{l}\text { First year of primary school (age 6) } \\
\text { School year: } 2008-2009\end{array}$ \\
\hline & $\begin{array}{l}\text { Assessment of children's initial } \\
\text { knowledge } \\
\text { Sample: } 813 \text { children and } 39 \text { classrooms }\end{array}$ & \\
\hline & \multicolumn{2}{|c|}{$\begin{array}{l}\text { Individual follow-up of the learning process for children in classrooms } \\
\text { with different teaching practices during the two school years } \\
\text { Sub-sample: } 214 \text { children and } 27 \text { classrooms } \\
\text { Interviews with teachers: Descriptive confirmation of the teaching practice } \\
\text { used in each classroom by means of interview }\end{array}$} \\
\hline & & $\begin{array}{l}\text { Assessment of performance in the } \\
\text { sub-sample at the end of the first year } \\
\text { of primary school: Learning targets }\end{array}$ \\
\hline
\end{tabular}

In the current paper we report the results of 214 boys and girls that were followed up during two school years (third year of preschool and first year of primary school). These participants are a sub-sample of the total of 813 children who were initially assessed at the start of the third year of preschool education. Specifically, the sub-sample comprised two groups of children significantly diffe- 
rentiated by level of performance. One of them including 108 children and the other one including 105 children who obtained the highest scores and lowest scores, respectively in the initial assessment. Performance levels were established with respect to the class, not the total sample. In each class the number of children form high level of performance and low level of performance was equal.

Children in the sub-sample were observed in the context of classroom activities during the two school years in question and their performance was assessed at the end of their first year of primary school ${ }^{2}$. The children were drawn from 27 classes at schools in Andalusia, Asturias, Cantabria, Leon, Catalonia, the region of Valencia, the Basque Country and Madrid. Most of the classes corresponded to state schools, with a minority drawn from private or state-assisted schools, and they showed different profiles of teaching practices.

\section{Defining learning targets}

The term learning targets refers to children's performance outcomes in reading and writing at the end of the first year of primary school. In order to define and assess these targets we took as our starting point the curricula that rule the teaching of reading and writing during the first cycle of primary education.

Given the multiplicity of educational contexts in Spain, and taking into account the different geographical regions covered by this study, it was necessary to define clearly the learning outcomes to be assessed so that the results obtained would be generalizable. With the implementation of the Law for the General Planning of the Educational System in 2000 most of Spain's Autonomous Communities (regional governments) gained full powers in the area of education. However, the current education law (Ley Orgánica de Educación 2/2006, May 3) has defined a set of "basic competencies" that are prescriptive for every community $(2 / 2006$, art. 6). These indicate that, for preschool, code-centred abilities are secondary to the functional uses of literacy (R.D. 1630/2006). A similar approach is proposed for the first cycle of primary school, although alongside this there is a growing concern for correct spelling. Literacy is considered a competency that should "cut-across" the curriculum, and therefore much time is dedicated to reading and writing in the specific content areas (R.D. 1513/2006).

In order to specify the learning targets we took as our starting point the learning objectives established for the end of the first year of primary school, and which feature in the curricula of each geographical region studied. At all events, the activities designed to assess children's performance in reading and writing, i.e. the learning targets, are learning objectives in all the geographical regions sampled in this study and, therefore, they fulfil the abovementioned requirement of generalizability (see Table 3). 


\section{Characterising the Learner's competencies}

The individual factors of each child cover all those elements that shape the whole of that child's reality (personal, cognitive, emotional and attitudinal factors), enable us to identify a learner's competencies. Mischel (1981) defines such competencies as what an individual can do, in other words, his or her maximum level of performance and the processes or content of awareness, expectations, attributions, beliefs, problem-solving strategies, and representation and conceptualisation of reality, etc. within the framework of the educational model. In the present study, however we have just focused in those factors supposedly involved in the process of their learning to read and write.

Taking as our starting point the numerous studies which have sought to detect the specific skills or aspects of knowledge that are thought to be involved in learning to read and write (i.e. visual and auditory perception, morphological awareness, phonological awareness, lexical knowledge, knowledge of letters and sounds), whether in order to determine the best predictors of learning (Casillas \& Goikoetxea, 2007; Foulin, 2005; Goikoetxea, 2005; Ortiz \& Guzmán, 2003) or to observe how these predictors change according to the child's learning stage (Lerkkanen, Rasku-Puttonen, Aunola \& Nurmi, 2004), we identified the competencies that should be assessed at the start of the third year of preschool education, age 5 and at the end of first grade of primary school (age 6) (see Table 2).

In the initial assessment we gathered information about how the children verbalised their ideas regarding: the function of reading; their knowledge of the name and sound of the letters in their own name and that of others; their ability to segment the syllables and sub-syllables of words chosen by the teacher from among the names of characters of various story-books; their lexical knowledge in a word definition task; their familiarity with text conventions and with the metalanguage associated with reading activities; and their familiarity with texts with a social use, in this case, a shop receipt and a newspaper. In order to assess their literacy performance, children were asked, in addition to writing their own name, to recognise words, to discover a spelling mistake and to write words with different numbers of syllables and a whole sentence.

\section{Defining classroom practices}

The aim of identifying teaching practices was addressed through three systems of data collection: questionnaire, interview and classroom observation. The first two of these provided a record of what teachers say they do when they teach reading and writing, whereas the classroom observation enabled us to compare what they say they do with what they actually $d o$. In terms of classroom experiences the observational data also allowed to us to produce a more nuanced, individualised and detailed description of their way of doing things and of the interactions that resulted from it. 
The questionnaire, developed in order to define profiles of teaching practices used to teach reading and writing in the final year of preschool education third year of preschool education, age 5 and the first year of primary school, comprised thirty items that required a response on a six-point Likert scale, depending on the frequency of the teaching practice in question ${ }^{3}$.

The content of the items was organised into four thematic blocks: 1) classroom organisation; 2) timetabling; 3) activities and content; and 4) assessment. We assume that teaching practices will differ according to classroom dynamics, the extent to which the teacher takes advantage of situational learning, the instructional activities used and the outcomes or product of learning 4 .

The questionnaire was administered to 2250 teachers, 1193 from preschool and 1057 from first year of elementary school and recorded in a systematic and reliable way the practices of teachers from different geographical regions of Spain (Almeria, Asturias, Cantabria, Catalonia, Madrid, Valencia, Leon, the Basque Country and Valladolid). The questionnaire was adapted to the principal language used in each of these settings (Spanish, Catalan or Basque). Of the total number of participants, $91 \%$ were female and $46 \%$ had more than six years experience at their current educational level. Sixty-two percent were aged over forty and $74 \%$ worked in state schools.

The factor analysis conducted as part of the statistical study 5 revealed four factors or dimensions that differentiated the teaching practices:

Factor I. Explicit instruction of the code in activities designed specifically for this purpose.

Factor II. Independent writing, situational learning.

Factor III. Products of learning, homogenisation.

Factor IV. Use of situations that arise, diversity of materials.

The cluster analysis of these factors revealed three profiles of teaching practice, which were very evenly distributed among the population studied. These profiles were termed instructional (greater frequency of factors I and III), situational (greater frequency of factors II and IV) and multidimensional (high frequency of all the factors). The characteristics of these profiles are as follows:

- Teachers who match the profile of instructional teaching practices (33.87\% of the sample) are those who state that they set aside a specific amount of time in the school timetable for reading and writing activities, who rely on children's knowledge of letters and the sounds they represent in order to teach reading and writing, who correct children when they guess instead of read, and who use activities to analyse the sounds formed by a spoken word.

- Teachers in the group of situational teaching practices (37.06\%) state that they frequently organise their reading and writing activities in small groups, make use of situations that 
arise in the classroom, plan their timetable in conjunction with teachers from other levels, decide what vocabulary to teach by taking into account the life experiences shared by children, assess progress by observing the independent writing of short texts, use a wide range of printed materials in class, and encourage children to write down the words they need even if they don't yet know the letters involved.

- Teachers assigned to the profile of multidimensional teaching practices $(29.06 \%)$ say that they set aside specific time for reading and writing activities, make use of children's knowledge of letters and sounds when teaching them to read and write, pay attention to the independent writing of short texts in order to assess children's progress, propose special activities to encourage reading out loud and, finally, work on reading and writing by using situations that arise in the classroom.

Having established the three types of teaching practices the in-depth interviews enabled us to determine the consistency between the practices declared in the questionnaire and the actual practice in the classroom (Fons \& Buisán, submitted). Is also facilitates to describe in finer detail the profiles that appeared in the observed classrooms, and to identify and understand more about the instructional choices made by each teacher. The interview schedule, which was based on the four thematic blocks of the questionnaire and on the items that loaded on each of the four factors, allowed us to produce a narrative account of what teachers say they do and their reasons for doing it. As the interviewee's narrative discourse is constructed it reveals his/her beliefs, representations and forms of knowledge about educational practice (Cambra \& Palou, 2007).

The interviewees were teachers from the classrooms chosen for the observation of reading and writing activities during the two academic years studied (third year of preschool education, age 5 and first year of elementary school). A total of 39 interviews were conducted with teachers from preschool and 32 with teachers from first year elementary school.

The interview data (annotated or recorded and transcribed) were analysed using certain concepts from discourse analysis (Calsamiglia \& Tusón, 1999; Cambra \& Palou, 2007; Kerbrat-Orecchioni, 2005; Palou, 2008). Specifically, we took into account the semantic axis, which enabled us to define what was being spoken about, which notions had an important place in the discourse, and what constellation of terms was associated with these notions. We also considered the appraisals and judgments made by the speaker and examined in depth the modal aspects of the discourse (use of pronouns, location in space and time, verbal modality, and possible metaphors and analogies). This analysis provided a more detailed account of what the interviewees say they do and of their explanations, reasoning, and conceptualisation regarding teaching practices.

Finally, the observation enabled us to compare what the teachers say they do (as stated in the interviews) with what they actually do in the classroom. The aim 
was to reveal the details that genuinely distinguish different ways of working in the classroom and the interactions produced therein. It was postulated that these data would prove crucial in terms of explaining the differences in learning processes. Observations were recorded for 27 classrooms in third year of preschool education, age 5 and a further 27 in first year of elementary school.

\section{Results}

\section{Learner's initial competencies}

Almost all the children that participate in the initial assessment at the third year of preschool education, age $5(98 \%)$ could write their name correctly and the large majority $(94.2 \%)$ said they enjoyed reading, even though some of them $(16 \%)$ said they weren't exactly sure what the point of reading and writing was. Among those who attributed some kind of function to reading, the majority $(66 \%)$ referred to it as a school task, a much smaller percentage (11\%) said that being able to read meant you were grown up, and a few children (4\%) saw reading as a form of recreation and communication. For each of the remaining tasks we calculated the mean number of correct responses as an initial measure of the children's performance. Table 2 shows the results for all the children who were observed, specifically, the mean number of correct responses with the corresponding standard deviation, the range, and the percentage of children who obtained the maximum score for each of the tasks at the initial assessment.

The final column shows the results of the two-tailed t-test applied to show that the means obtained differed significantly according to the initial level of performance. It can be seen that the difference between high and low performers was significant for all the tasks assessed (see Table 2).

These results suggest that children begin the final year of preschool education with greater knowledge of letter names than of the sounds that these represent. Only $18.7 \%$ of the participants were able to show that they knew the sound of the letters in their own name and that of others. With respect to metaphonological skills, the children found it much easier to segment words into syllables than into sub-syllables. The word definition task generally proved very difficult. Only a tiny percentage clearly understood basic text conventions or demonstrated familiarity with texts that have a social use. However, more than half the children recognised written words and spelling mistakes, even though fewer than $10 \%$ of them could write words and sentences alphabetically. All the levels of writing development are represented in the last year of preschool education and a small percentage of children have already mastered alphabetic writing. 
Table 2. Competencies assessed and the results of the initial assessment $(n=214)$

\begin{tabular}{|c|c|c|c|c|c|}
\hline $\begin{array}{l}\text { Competencies } \\
\text { assessed }\end{array}$ & & Mean $(\mathrm{SD})$ & Range & $\begin{array}{l}\% \text { max. } \\
\text { score }\end{array}$ & $\begin{array}{c}t \text {-test } \\
\text { initial level }\end{array}$ \\
\hline $\begin{array}{l}\text { Enjoyment and } \\
\text { function of reading }\end{array}$ & $\begin{array}{l}\text { Interview: Child's } \\
\text { ideas about the } \\
\text { function of reading } \\
\text { and whether s/he } \\
\text { likes to read. }\end{array}$ & & & & \\
\hline \multirow[t]{2}{*}{$\begin{array}{l}\text { Knowledge of the } \\
\text { writing system }\end{array}$} & $\begin{array}{l}\text { Knowledge of letter } \\
\text { names (Max: 2) }\end{array}$ & $1.34(.85)$ & $0-2$ & 59.3 & $\begin{array}{c}t(212)=2.917 \\
p=.004\end{array}$ \\
\hline & $\begin{array}{l}\text { Knowledge of letter } \\
\text { sounds (own name } \\
\text { and that of others) } \\
\text { (Max: 2) }\end{array}$ & $.47(.79)$ & $0-2$ & 18.7 & $\begin{array}{c}t(212)=19.048 \\
p=.000\end{array}$ \\
\hline \multirow{2}{*}{$\begin{array}{l}\text { Metaphonological, } \\
\text { sub-syllabic and } \\
\text { syllabic knowledge }\end{array}$} & $\begin{array}{l}\text { Syllabic segmentation } \\
\text { (Max: 4) }\end{array}$ & $2.39(1.55)$ & $0-4$ & 36.0 & $\begin{array}{c}(213)=7.654 \\
p=.000\end{array}$ \\
\hline & $\begin{array}{l}\text { Sub-syllabic segmen- } \\
\text { tation (Max: } 4 \text { ) }\end{array}$ & $.26(.88)$ & $0-4$ & 3.7 & $\begin{array}{c}\mathrm{t}(212)=20.517 \\
\mathrm{p}=.000\end{array}$ \\
\hline Lexical knowledge & $\begin{array}{l}\text { Word definition } \\
\text { (Max: 8) }\end{array}$ & $3.95(1.85)$ & $0-7.78$ & 0.5 & $\begin{array}{c}\mathrm{t}(211)=-20.299 ; \\
\mathrm{p}=.000\end{array}$ \\
\hline Text conventions & $\begin{array}{l}\text { Detecting the lack of } \\
\text { a title in a story } \\
\text { Naming the title } \\
\text { (Max: 2) }\end{array}$ & $.80(.67)$ & $0-2$ & 14.0 & $\begin{array}{c}t(209)=33.982 ; \\
p=.000\end{array}$ \\
\hline \multirow[t]{2}{*}{$\begin{array}{l}\text { Social uses of } \\
\text { language }\end{array}$} & $\begin{array}{l}\text { Texts with a social } \\
\text { use: newspaper } \\
\text { (Max: } 8 \text { ) }\end{array}$ & $4.29(1.85)$ & $0-8$ & 4.2 & $\begin{array}{c}t(210)=23.221 \\
p=.000\end{array}$ \\
\hline & $\begin{array}{l}\text { Texts with a social } \\
\text { use: shop receipt } \\
\text { (Max: } 8 \text { ) }\end{array}$ & $2.94(1.92)$ & $0-7$ & 0.0 & $\begin{array}{c}t(212)=-11.539 ; \\
p=.000\end{array}$ \\
\hline \multirow[t]{2}{*}{$\begin{array}{l}\text { Initial reading } \\
\text { performance }\end{array}$} & $\begin{array}{l}\text { Word recognition } \\
\text { (Max: 4) }\end{array}$ & $2.96(1.24)$ & $1-4$ & 54.7 & $\begin{array}{c}\mathrm{t}(213)=-19.117 ; \\
\mathrm{p}=.000\end{array}$ \\
\hline & $\begin{array}{l}\text { Recognising spelling } \\
\text { mistakes (Max: 4) }\end{array}$ & $1.99(1.31)$ & $1-4$ & 28.0 & $\begin{array}{c}\mathrm{t}(213)=-5.679 \\
\mathrm{p}=.000\end{array}$ \\
\hline \multirow[t]{2}{*}{$\begin{array}{l}\text { Initial writing } \\
\text { performance }\end{array}$} & $\begin{array}{l}\text { Writing words } \\
\text { (Max: } 5\end{array}$ & $2.73(1.34)$ & $1-5$ & 0.9 & $\begin{array}{c}\mathrm{t}(187)=-14.766 ; \\
\mathrm{p}=.000\end{array}$ \\
\hline & $\begin{array}{l}\text { Writing sentences } \\
\text { (Max: 5) }\end{array}$ & $1.99(1.31)$ & $1-5$ & 0.5 & $\begin{array}{c}\mathrm{t}(161)=-10.699 ; \\
\mathrm{p}=.000\end{array}$ \\
\hline
\end{tabular}

\section{Learner's accomplishments of learning targets}

Table 3 shows the results for each learning target of the final assessment of reading and writing. The cluster analysis groups the children's responses into three categories according to their performance (high, intermediate and low) in reading and writing (see Table 3 ). 
Table 3. Final performance: assessment of reading and writing outcomes $(N=214)$

\begin{tabular}{|c|c|c|c|}
\hline & \multicolumn{3}{|c|}{ Level } \\
\hline & High & $\begin{array}{c}\text { Interme- } \\
\text { diate }\end{array}$ & Low \\
\hline \multicolumn{3}{|l|}{ Writing } & \\
\hline Writing words (Max: 5) & 4.67 & 4.35 & 3.13 \\
\hline Writing sentences (Max: 5) & 4.24 & 4.00 & 3.00 \\
\hline Conventional phonographic writing of specific syllables (Max: 12) & 11.31 & 8.70 & 2.38 \\
\hline Correct spelling of words with different syllabic structures (Max: 10) & 7.45 & 4.52 & 0.91 \\
\hline \multicolumn{4}{|l|}{ Reading } \\
\hline Recognising mistakes (Max: 4) & 4.00 & 3.00 & 2.00 \\
\hline Sentence comprehension (Max: 8) & 7.46 & 7.08 & 0.60 \\
\hline Separation of words in the sentence (Max: 10) & 8.99 & 3.97 & 2.98 \\
\hline Word recognition (Max: 4) & 4.00 & 4.00 & 3.00 \\
\hline
\end{tabular}

In terms of reading, half the children assessed at the end of first year of elementary school were able to identify all the words presented, recognise and explain a spelling mistake, and understand almost all the written sentences they were shown. However, they still had difficulties in separating the words of a sentence. A slightly smaller percentage had no problems in recognising words or detecting a spelling mistake but could not explain it. This sub-group found it a little more difficult to understand sentences and had difficulties in separating graphically the words of a sentence. There was also a smaller percentage of children whose performance was well below average.

The pattern of results was similar for writing, although performance was slightly better. By the end of the first year of primary school most of the children could write words and sentences with a wide range of syllabic structures, not only alphabetically but, in many cases, orthographically. Indeed, the highest performers were close to achieving orthographic writing. A somewhat lower percentage could write alphabetically, respecting phonographic correspondences, but were some way from writing orthographically. As before, a small group of children performed well below the average: they had yet to achieve the alphabetic level and some of them could still not differentiate letters when writing. 
Learner's initial knowledge, teaching practices and learning outcomes

The results obtained enable us to examine the relative contribution of the learner and of teaching practices as regards reading and writing performance. Specifically, one can consider the extent to which children's performance at the end of first grade is associated with the teaching profile that characterized a given classroom (instructional, situational or multidimensional) with the child's initial literacy level or with any of the other variables of the study. To this end we applied a series of chi-squared tests to each of the study variables (teaching practices, child's initial level, geographical region and type of school) and the measures of reading and writing performance at the end of first grade.

The results showed that the only variable which was significantly associated with final performance was the child's initial ability level, this being the case for both writing $\left(\mathrm{x}^{2}(2, \mathrm{~N}=214)=21.517, p=.000\right)$ and reading $\left(\mathrm{x}^{2}(2, \mathrm{~N}=214)=\right.$ 29.019, $p=.000)$.

The first point to note, therefore, is that the results of this macro study about children's initial knowledge and their final performance in relation to teaching practices demonstrate that the classroom profile (situational, instructional or multidimensional teaching practices) does not have a statistically significant effect on the observed outcomes (high, intermediate or low performance). Specifically, no significant differences were observed in the scores obtained for reading and writing tasks at the end of the first year of primary school by children in classrooms with a different profile of teaching practices.

However, attention should be paid to certain findings from the general study that show, with notably balanced distributions, that there are more highperforming children in multidimensional classrooms, suggesting that such classrooms are better able to foster children's performance (see Figure 1).

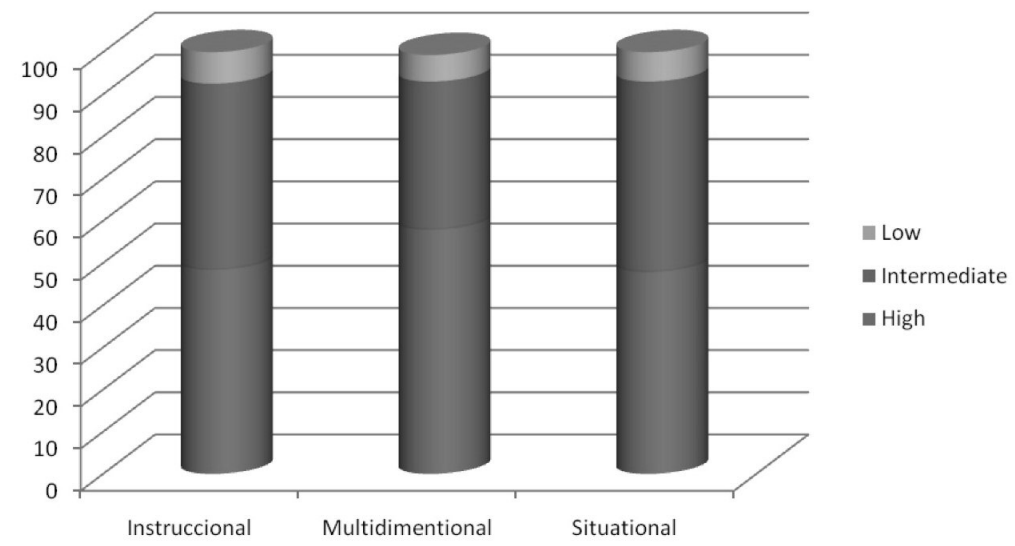

Figure 1. Teaching profiles and children's performance 
These results also suggest that early and repeated teaching of the relationships between letter forms/sounds and metaphonological aspects, as well as the establishment of fixed timetables and specific activities for teaching the written code separately from oral language teaching (systematic activities to which much time is dedicated in the instructional profile) do not appear to be of key importance as regards children's knowledge at the end of the first year of primary school. Children in situational and multidimensional classrooms obtain the same results on these types of task.

Given these findings it is necessary to examine more closely the different classroom profiles in order to determine which aspects may be influencing written language learning, particularly in relation to the actual practices that are followed. In this regard the classroom observations and the analysis of interactions enable us to compare ways of doing things and provide a basis on which to establish differences between the three profiles. Conclusions can then be drawn regarding the teaching conditions associated with each of the different contexts (see Table 4).

\section{Table 4: Comparative chart of classrooms with a different profile}

\begin{tabular}{|c|c|c|}
\hline Situational classroom & Instructional classroom & Multidimensional classroom \\
\hline Dynamics and interaction & Dynamics and interaction & Dynamics and interaction \\
\hline $\begin{array}{l}\text { Activities involving interaction, } \\
\text { participation, adaptation to the } \\
\text { immediate environment, collabo- } \\
\text { ration and spontaneous inter- } \\
\text { vention on the part of the } \\
\text { children. } \\
\text { Long and complex learning } \\
\text { situations. } \\
\text { Varied range of teacher- } \\
\text { children interactions. }\end{array}$ & $\begin{array}{l}\text { No unforeseen events or situa- } \\
\text { tions that might prove discon- } \\
\text { certing. } \\
\text { Children participate when } \\
\text { asked to do so by the teacher, or } \\
\text { in order to clarify aspects of the } \\
\text { task. } \\
\text { Simple and linear situations. } \\
\text { One-way interactions: teacher- } \\
\text { children-teacher. }\end{array}$ & $\begin{array}{l}\text { In addition to using the } \\
\text { published teaching material } \\
\text { (work sheets/books) the teacher } \\
\text { makes use of other activities to } \\
\text { promote independent and } \\
\text { functional writing. } \\
\text { Teaching situations have a } \\
\text { different length and level of diffi- } \\
\text { culty: some are simple and linear } \\
\text { while others are longer and more } \\
\text { complex. } \\
\text { Complex interactions in } \\
\text { various directions: children- } \\
\text { teacher - children - children. }\end{array}$ \\
\hline Tasks & Tasks & Tasks \\
\hline $\begin{array}{l}\text { Use of situations that arise, } \\
\text { work on the functions of texts, } \\
\text { reading and writing with a } \\
\text { purpose, in a contextualised way, } \\
\text { use of specific vocabulary, } \\
\text { attention to the relationship } \\
\text { between letter forms and sounds } \\
\text { so as to decode the text. } \\
\text { Relationship between the } \\
\text { children and texts, and with one } \\
\text { another, so as to promote } \\
\text { reflection on metalinguistic } \\
\text { production. } \\
\text { Correcting mistakes in one's } \\
\text { own production. }\end{array}$ & $\begin{array}{l}\text { Work on isolated concepts, } \\
\text { detection of sounds and letters or } \\
\text { joining them with arrows } \\
\text { indicating concepts or terms. Use } \\
\text { of repetition as a way of learning. } \\
\text { Reading and writing: school } \\
\text { tasks, without communicative } \\
\text { functions. } \\
\text { Work is corrected separately } \\
\text { from the process through which } \\
\text { texts are produced. } \\
\text { Reflection upon semantic and } \\
\text { morphological aspects. }\end{array}$ & $\begin{array}{l}\text { Use of different tasks: those of } \\
\text { the official method (work books, } \\
\text { games, cards, dictation) and } \\
\text { others designed to produce } \\
\text { functional texts, in which reading } \\
\text { and writing are used for a } \\
\text { purpose that goes beyond a } \\
\text { simple school task. } \\
\text { Corrections are made while the } \\
\text { child is present, inviting them to } \\
\text { reflect upon their work. } \\
\text { Texts are worked on orally and } \\
\text { in groups, before moving on to } \\
\text { an individual writing task. }\end{array}$ \\
\hline
\end{tabular}




\begin{tabular}{|c|c|c|}
\hline Content & Content & Content \\
\hline $\begin{array}{l}\text { Greater complexity, greater } \\
\text { communicative challenge. } \\
\text { Function of reading and writing. } \\
\text { Vocabulary. } \\
\text { Familiarity with texts and } \\
\text { naming the different aspects of } \\
\text { text organisation. } \\
\text { Writing, word } \\
\text { identification/reading. }\end{array}$ & $\begin{array}{l}\text { Uniform task difficulty. } \\
\text { Tasks: only one attempt. } \\
\text { Word identification. } \\
\text { Underlining. } \\
\text { Writing words. } \\
\text { Handwriting. } \\
\text { Vocabulary, nominal morphology. } \\
\text { Names and sounds of letters }\end{array}$ & $\begin{array}{l}\text { Reading words and texts. } \\
\text { Closed tasks when applying } \\
\text { the official method, but open } \\
\text { tasks for text production. } \\
\text { Writing words and texts. } \\
\text { Names and sounds of letters }\end{array}$ \\
\hline
\end{tabular}

From the above table it can be concluded that the activities carried out in a classroom whose teacher is characterized by a situational profile offer children more opportunities to communicate by writing, develop their initiative, gain enjoyment from learning and sharing, and increase their knowledge about written texts. The content of the classroom whose teacher is characterized by an instructional profile is less contextualised and offers fewer challenges, the activities being more predictable and likely to foster more homogenous learning. The classroom whose teacher is characterized by a multidimensional profile offers children a variety of activities that combine aspects of the situational and the instructional profile. In other words, children take part in activities whose characteristics, content and level of complexity are all varied, and which accompany the more systematic tasks designed to teach them the code.

\section{Classroom interactions and strategies}

An additional objective of the study was to identify differential characteristics of the interactions and strategies used by children in the classroom setting which may explain the progress or delay shown by some pupils when learning to read and write. To this end we identified the patterns of progress or delay by comparing the results obtained in the initial assessment (in which two performance levels were established: high and low) with those obtained in the final assessment (three levels: high, intermediate and low); the results for reading and writing were compared separately. Once these patterns had been identified we analysed in detail the observations made of these children in order to search for differential characteristics that would help us understand their learning trajectory. The premise here was that a detailed analysis of interactions would provide important clues to understanding this trajectory.

When analysing the interactions of children who were initially low performers in reading and writing we found a series of common features in terms of their classroom behaviour. Firstly, they all depended heavily on the teacher asking them to do something before making a contribution, whether in the context of individual or group tasks. However, this kind of dependency followed a 
continuum, it being more marked among those who showed the least progress. A similar pattern was observed in their interactions with peers: the more dependent children sought much more attention from their classmates, while the least dependent had developed ways of making contributions to individual and group tasks, and were able to give information and discuss it. A further characteristic of this group of children was their lack of attention to the objectives of the task being carried out. In sum, the analysis of classroom observations illustrates three aspects that are associated with the different results obtained by some of the low performers: attention, the ability to take an active part in the learning process and the ability to interact so as to give information. Finally, it should be noted that the classroom observations also revealed that the teachers worked in the same way with all the pupils, in other words, they did not pay greater attention to the slowest learners.

\section{Conclusions}

Having reliably defined three profiles of teaching practices on the basis of the questionnaire, the interviews and classroom observations then enabled us to locate each teacher within a given profile. The resulting data regarding teachers' explanations, justifications, actual ways of doing things and teaching experiences brought greater detail to the three profiles of literacy teaching.

We found marked differences in children's knowledge at the preschool level, and this initial knowledge had a significant influence on their subsequent performance. Despite having identified three well-differentiated profiles of teaching practices, the skills and knowledge that children bring with them when starting the third year of preschool ${ }^{6}$ appear to be fundamental in determining their literacy performance at the end of first year of elementary school. Indeed, this learning background seems to make a greater contribution to learning outcomes than do teaching practices: in the sample as a whole we found no significant effect of teaching practices on children's reading and writing performance at the end of the first year of primary school, whereas their initial ability level did have a significant influence.

The observation of classroom interactions provided clues as to why there were differences between some children and others. Specifically, the observed interactions suggested that children's attention capacity, whether or not they were able to take an active part in the learning process, and their ability to interact in order to give information were all relevant factors in this regard. In order to confirm that these factors can indeed explain the observed differences it will be necessary to analyse the interactions of other children from the sample. 
We also noted only minimal variations in the teachers' interventions with respect to the specific characteristics of their pupils. Although the teaching profiles showed important differences in terms of classroom organisation, content, timetabling and assessment, the observation of interactions revealed a certain uniformity of teaching practices, despite the considerable differences in children's performance and their ways of interacting. In this context, we believe that teacher training should seek to promote well-differentiated teaching strategies. Indeed, it would be interesting to see what would happen if special attention was paid to the slowest learners as soon as their delay was identified, rather than waiting until their results lead them to be regarded as failing at school. Although the school system does have resources for slow learners, these do not become available until later in a child's schooling, once they are already in primary school. Attention and individual input at the ages of three and four should, however, help them from the outset as regards motivational aspects and their ability to interact and ask for help.

The individualised observation conducted during this study revealed certain processes that appear to help promote learning and which are related to learners' ability to manage task objectives and their interactions with both peers and the teacher. Specifically, the slowest learners are those who have most difficulties in managing these three aspects, and they are more dependent on the teacher and on the information they may receive from their classmates. In other words, certain dynamics and factors that are not inherently part of the reading and writing process influence their learning. This observation illustrates the important contribution of general socio-affective aspects to a specific learning domain such as literacy, and highlights, therefore, the problem of limiting our explanations of children's progress and delay merely to the specific features of written language. It should be borne in mind, however, that much work has yet to be done in terms of analysing the classroom tasks and the two dimensions of interactions observed. Indeed, the enormous amount of material generated by our research project, of which the present study forms only a part, is far from being analysed in its entirety. Our present aim is to examine this material in the search for strategies and mechanisms that are directly involved with the process of learning to read and write, both as regards learners and teachers, and which may help to explain children's different learning trajectories.

The analysis of assessment profiles showed that the children made only limited progress as regards their performance level. Although there was a two-year interval between the two assessment points, many children remained close to their initial performance level. Those who do make progress are most likely to do so in writing rather than in reading. This finding could be related to a number of factors. Firstly, in order to reach the maximum level in the writing assessment used, the children had to master the spelling of words with a different syllabic 
structure, whereas the reading assessment was based on aspects of comprehension, which is a much broader domain that brings together a greater number of skills. We believe that in order for these two aspects to be comparable the writing assessment would need to include aspects of text production rather than just spelling. In general, an important limitation of the present study is that it does not consider tasks involving text production, a type of task that is more likely to reveal greater individual differences, as well as a higher incidence of teaching practices.

To conclude, although this macro study shows that teaching/learning conditions do not produce notable differences in children's performance, the analysis of classroom dynamics suggests that the situational and multidimensional profiles are potentially richer and offer children more opportunities in terms of independent writing, the capacity to reflect and make use of higher-level thought functions, and the possibility of learning to read and write in more meaningful contexts of social interaction. In light of what we know today, the learning that takes place in these classrooms should be more closely matched to the objectives of the school as a social institution. Nevertheless, the data need to be analysed in greater depth so as to examine qualitatively, with a larger number of classrooms and children, the findings that are presently drawn from a small sample. Also, a more systematic analysis of all the intervening variables is needed in order to precise possible interactions that are not contemplated in the present study.

There also remains another important question to resolve. The study has shown that teachers guide children towards their learning targets regardless of the practices used, yet it is not clear whether all the teaching profiles observed are equally appropriate and useful in terms of helping children master the wider aspects of literacy.

\section{Notes}

1 Part of the research project The conditions of initial written language learning: the influence of current classroom practices and pupils' prior knowledge (SEJ2006-05292), subsidised by the Ministry of Education and Science (MEDU), National Programme of Social, Economic and Legal Sciences (NSEJ), National Plan for R+D+I (2004-2007). PI: Liliana Tolchinsky

2 For the final assessment the tasks were always presented in the same order and performed in the context of an individual interview.

3 The questionnaire can be consulted at http://ice.ub.es/recerca/butlleti/llistat.htm: Alba, C., Tolchinsky, L. \& Buisán, C. (2008). Un instrument per identificar les pràctiques docents per ensenyar a llegir i escriure [An instrument for identifying the teaching practices used to teach reading and writing]. [Online] Bulletí LaRecerca, 10. Secció de Recerca, Institut de Ciències de l'Educació.

4 Classroom dynamics: type and accessibility of printed material and available texts, groups 
established for classroom work, organisation of the space, etc. Taking advantage of situational learning: opportunities for independent writing, use of situations that arise in order to teach vocabulary or carry out writing tasks, etc. Instructional activities: letter recognition, systematic teaching of letter/sound relationships, explicit analysis of word sounds, etc. Consideration of the outcome or product of learning: emphasis on correct decoding and good handwriting, or on the absence of spelling mistakes as indicators of effective learning, etc.

5 The development process, the data analysis and the results obtained can be consulted in González X.A., Buisán, C. \& Sánchez, S. (2009). Las prácticas docentes para enseñar a leer y escribir [Teaching practices used to teach reading and writing]. Infancia y Aprendizaje, 32 (2), 153-169.

6 In Spain, children start school at age three. Therefore, the children in this study had already had two years of fairly systematic contact with written language, in addition to the contribution of their family.

\section{References}

Aram, D. \& Besser, S. (2009). La intervención en la alfabetización temprana: ¿Qué actividades se deben incluir? ¿a qué edad se debe comenzar? y ¿quién debe llevarlas a cabo? Infancia y Aprendizaje, 32 (2), 171-187.

Aronoff, M. (1994). Spelling and culture. In W. C. Watt (Ed.), Writing systems and cognition (pp. 67-87). Dordrecht: Kluwer.

Artiles, C. (1997). Influencia de los métodos de enseñanza en el desarrollo de los procesos léxicos. Tesis doctoral no publicada, Universidad de la Laguna, Tenerife.

Baker, L., Scher, D. \& Mackler, K. (1997). Home and family influences on motivations for reading. Educational Psychologist, 32 (2), 69-82.

Barrio, J. L. (2006). La querella dels mètodes: Un final per decret. Articles de Didàctica de la Llengua i la Literatura, 40, 89-112.

Brice-Heath, S. (1983). Ways with words: Language, life and work in communities and classrooms. New York: Oxford University Press.

Bus, A. G., van Ijzendoorn, M. H. \& Pellegrini, A. D. (1995). Joint book reading makes for success in learning to read: A meta-analysis on intergenerational transmission of literacy. Review of Educational Research, 65 (1), 1-21.

Calsamiglia, H. \& Tusón, A. (1999). Las cosas del decir. Manual de análisis del discurso. Barcelona: Ariel.

Cambra, M. \& Palou, J. (2007). Creencias, representaciones y saberes de los profesores de lenguas en las nuevas situaciones plurilingües escolares de Cataluña. Cultura \& Educación, 19 (2), 149-163.

Cardoso-Martins, C. (2001). The reading abilities of beginning readers of Brazilian Portuguese: Implications for a theory of reading acquisition. Scientific Studies of Reading, 5, 289317.

Casillas, A. \& Goikoetxea, E. (2007). Sílaba, principio-rima y fonema como predictores de la lectura y escritura tempranas. Infancia y Aprendizaje, 30 (2), 245-259.

Castells, N. (2006). L'aprenentatge de la lectura inicial: Una aproximació als coneixements dels infants $i$ a les estratègies d'ensenyament. Tesis Doctoral, Universidade de Barcelona. Retrieved 24/05/2011 from http://www.tesisenred.net/TDX-0129107-124121

Chafe, W. \& Danielewicz., J. (1987). Properties of spoken and written language. In R. Horowitz \& S. J. Samuels (Ed.), Comprehending oral and written language (pp. 83-113). San Diego: Academic Press. 
Chall, J. S. (1967). Learning to read: The great debate. New York: McGraw-Hill.

Clemente, M. \& Domínguez, A. B. (1999). La enseñanza de la lectura: Un enfoque psicolingüístico y sociocultural. Madrid: Pirámide.

Coltheart, M. (1985). Cognitive neuropsychology and the study of reading. In M. I. Posner \& O. S. M. Marin (Ed.), Attention and Performance XI (pp. 3-37). Hilsdale, NJ: Lawrence Erlbaum Associates Inc.

Coltheart, M., Curtis, B., Atkins, P. \& Haller, M. (1993). Models of reading aloud: Dualroute and parallel distributed-processing approaches. Psychological Review, 100 (4), 589608.

Connelly, V., Johnston, R. \& Thompson, G. B. (2001). The effect of phonics instruction on the reading comprehension of beginning readers. Reading and Writing: An Interdisciplinary Journal, 14 (5-6), 423-457.

Connor, C. M., Morrison, F. J. \& Katch, L. (2004). Beyond the reading wars: Exploring the effect of child-instruction interactions on growth in early reading. Scientific Studies of Reading, 8 (4), 305-336.

Craig, S. A. (2006). The effects of an adapted interactive writing intervention on Kindergarten's children's phonological awareness, spelling, and early reading development: A contextualized approach to instruction. Journal of Educational Psychology, 98 (4), 714-731.

Defior, S. \& Alegría, J. (2005). Conexión entre morfosintaxis y escritura: Cuando la fonología es (casi) suficiente para escribir. Revista de Logopedia, Foniatría y Audiología, 25 (2), 51-61.

Ellis, A. W. (1982). Spelling and writing (and reading and speaking). In A. W. Ellis (Ed.), Normality and Pathology in Cognitive Functions (pp. 113-146). London: Academic Press.

Foulin, J. N. (2005). Why is letter-name knowledge such a good predictor of learning to read? Reading and Writing: An Interdisciplinary Journal, 18 (2), 129-155.

Goikoetxea, E. (2005). Levels of phonological awareness in preliterate and literate Spanish-speaking children. Reading and Writing: An Interdisciplinary Journal, 18 (1), 5179.

Goody, J. \& Watt, I. (1963). The consequences of literacy. Contemporary Studies in Society and History, 5, 304-345.

Hoefflin, G., Cusinay, M., Pini, G., Rouèche, A. \& Gombert, J. E. (2007, June). Sensibilisation à l'écrit chez des élèves de 5 à 6 ans dans le contexte d'approches pédagogiques variées. Conferencia invitada al III Seminari sobre contextos d'ensenyament i aprenentatge de la llengua escrita. Barcelona.

Jiménez, J. \& Guzmán, R. (2003). The influence of code-oriented versus meaning-oriented approaches to reading instruction on word recognition in the Spanish language. International Journal of Psychology, 38 (2), 65-78.

Jong, P. \& Leseman, P. (2001). Lasting effects of home literacy on reading achievement in school. Journal of School Psychology, 39 (5), 389-414.

Kerbrat-Orecchioni, C. (2005). Le discours en interaction. Paris: Armand Colin.

Lahire, B. (1995). Tableaux de familles. Paris: Seuil.

Lerkkanen, M., Rasku-Puttonen, H., Aunola, K. \& Nurmi, J. (2004). Predicting reading performance during the first and the second year of primary school. British Educational Research Journal, 30 (1), 67-92.

Ley Orgánica (2006, May). Ley orgánica de educación. In Spain Official Bulletin (BOE) (No. 106) (pp. 17158-17207). Madrid.

Linklater, D. L., O’Connor, R. E. \& Palardy, G. J. (2009). Kindergarten literacy assessment of English Only and English language learner students: An examination of the predictive validity of three phonemic awareness measures. Journal of School Psychology, 47 (6), 369394.

McBride-Chang, C. (1999). The ABCs of the ABCs: The development of letter-name and letter-sound knowledge. Merrill-Palmer Quarterly, 45 (2), 285-308. 
McKeown, M. \& Beck, I. L. (2006). Encouraging young children's interactions with stories. In D. K. Dickinson \& S. B. Neuman (Ed.), Handbook of early literacy research (2nd ed.) (pp. 281-294). New York: Guilford Press.

Mischel, W. (1981). A cognitive-social learning approach to assessment. In T. V. Merluzzi, C. R. Glass \& M. Genest (Ed.), Cognitive Assessment (pp. 479-502). New York: Guilford Press.

Morani, M. \& Pontecorvo, C. (1995). Invenzione e scrittura di storie in coppie di bambini. Età evolutiva, 51, 81-92.

Olson, D. R. (1991). Literacy and objectivity: The rise of modern science. In D. R. Olson \& N. Torrance (Ed.), Literacy and orality (pp. 149-164). Cambridge: University Press.

Ong, W. J. (1992). Writing is a technology that restructures thought. In P. Downing, S. D. Lima \& M. Noonan (Ed.), The linguistics of literacy (pp. 293-319). Amsterdam: John Benjamins.

Ortiz, M. R. \& Guzmán, R. (2003). Contribución de la percepción del habla y la conciencia fonémica a la lectura de palabras. Cognitiva, 15 (1), 3-17.

Palincsar, A. S. (1998). Social constructivist perspectives on teaching and learning. Annual Review of Psychology, 49, 345-375.

Palou, J. (2008). L'Ensenyament i l'aprenentatge del català com a primera llengua a l'escola. Creences $i$ actuacions dels mestres amb relació a les activitats de llengua oral a l'etapa primària. Barcelona: Institut d'Estudis Catalans.

Pascucci, M. (1995). La costruzione di storie in gruppi di pari dalla seconda alla quinta elementare. Età evolutiva, 51, 93-101.

Patterson, K. A. \& Morton, J. (1985). From orthography to phonology: An attempt at an old interpretation. In K. E. Patterson, J. C. Marshall \& M. Coltheart. (Ed), Surface Dyslexia, Neuropsychological and Cognitive Studies of Phonological Reading (pp. 335-359). New Jersey: Erlbaum Hillsdale.

Pennington, B. F. \& Lefly, D. L. (2001). Early reading development in children at family risk for dyslexia. Child Development, 72 (3), 816-833.

Pentimonti, J. M. \& Justice, L. (2010). Teachers' use of scaffolding strategies during read alouds in the preschool classroom. Early Childhood Education Journal, 37 (4), 241-248.

Pressley, M., Wharton-Macdonald, R., Allington, R., Collins Block, C., Morrow, L., Tracey, D., Baker, K., Brooks, G., Cronin, J., Nelson, E. \& Woo, D. (2001). A study of effective first-grade literacy instruction. Scientifics Studies of Reading, 5 (1), 35-58.

Ribera, P. (2002). La producció de gèneres escrits en alumnes de cinc anys: Una perspectiva des de l'ensenyament. Tesis Doctoral, Universitat de València. Retrieved 24/05/2011 from http://www.tdx.cat/handle/10803/9626

Riley, J. L. (1996). The ability to label the letters of the alphabet at school entry: A discussion on its value. Journal of Research in Reading, 19 (2), 87-101.

Ríos, I. (1999). Les intervencions de la mestra en el procés de planificació oral de text escrit. Tesis Doctoral, Universitat Jaume I de Castelló. Retrieved 24/05/2011 from http://www.tesisenred.net/TDX-0523103-092617

Seymour, P. H. K. \& Evans, H. M. (1994). Levels of phonological awareness and learning to read. Reading and Writing: An Interdisciplinary Journal, 6 (3), 221-250.

Teberosky, A. (1992). Aprendiendo a escribir. Barcelona: ICE/Horsori.

Wagner, R. K., Torgesen, J. K., Laughon, P., Simmons, K. \& Rashotte, C. A. (1993). Development of young readers' phonological processing abilities. Journal of Educational Psychology, 85 (1), 83-103.

Zavala, V., Niño-Murcia, M. \& Ames, P. (Ed.). (2004). Escritura y sociedad. Nuevas perspectivas teóricas y etnográficas. Lima: Red para el desarrollo de las ciencias sociales en el Perú. 
Key words: Literacy learning, Pedagogical practices, Emerging literacy knowledge, Classroom interactions

\section{Schriftspracherwerb: der Beitrag von Unterrichtspraktiken und Vorwissen der Schülerinnen und Schüler}

\section{Zusammenfassung}

Wie bei anderen Lernprozesse wird auch der Schriftspracherwerb durch Wechselwirkungen zwischen Vorwissen der Kinder und den Lernangeboten im Unterricht bedingt. Die vorliegende Studie verfolgte drei Ziele: Erstens sollte gezeigt werden, über welche frühen literalen Fähigkeiten die Kinder zu Beginn des dritten Jahres der Vorschule verfügen. Dabei lag der Fokus auf begrifflichen und textlichen Fähigkeiten. Zweitens sollte detailliert beschrieben werden, welche Unterrichtspraktiken die Lehrpersonen beim Schriftspracherwerb in neun Regionen Spaniens verwenden. Drittens sollten Bezüge zwischen diesen beiden Faktoren und den schriftsprachlichen Leistungen der Kinder am Ende des ersten Primarschuljahres untersucht werden. Die Analysen der Unterrichtspraktiken haben drei deutlich unterschiedliche Muster der literalen Förderung ergeben. Die Ergebnisse der Studie zeigen jedoch, dass die schriftsprachlichen Leistungen der Schülerinnen und Schüler am Ende der ersten Klasse stärker mit ihren sprachlichen Vorkenntnissen zusammenhängen als mit dem Unterricht, den sie erfahren haben.

Durch detaillierte Beobachtungen von schulischen Lernsituationen konnten unterschiedliche Erwerbsverläufe identifiziert werden. Dabei wurde deutlich, dass sozio-affektive und einstellungsbezogene Aspekte für die unterschiedlichen schulischen Lernprozesse eine wichtige Rolle spielen.

Schlagworte: Sprachlernen, Unterrichtspraktiken, frühe literale Fähigkeiten, soziale Interaktionen im Unterricht

\section{La contribution des pratiques enseignantes et des connaissances des élèves aux apprentissages de la littéracie}

Résumé

L'apprentissage de la langue écrite résulte de l'interaction conjuguée des connaissances littéraciques construites par les enfants et à travers les enseignements qu'ils reçoivent. La présente étude vise trois buts: 1. Montrer quelles sont les connaissances littéraciques émergentes des enfants au début de la troisième année d'école enfantine du point de vue des dimensions notionnelles et textuelles; 2 . Donner une image détaillée des pratiques enseignantes en lien avec l'enseignement initial 
de l'écrit de neuf régions d'Espagne; 3. Déterminer la relation entre ces deux facteurs et les résultats des apprentissages de l'écrit à la fin de la première année de l'école primaire.

Trois profils d'enseignement bien différents ont été identifiés, et malgré ces différences, l'analyse montre que les capacités en langue écrite des élèves sont plus fortement associées à leur niveau de connaissances initiales qu'à l'enseignement qu'ils ont reçu.

Une observation détaillée des tâches conduites en classe a également permis d'identifier des trajectoires d'apprentissage différentes. Cette observation met en évidence le rôle des dimensions socio affectives et comportementales qui peuvent expliquer les différences d'apprentissages des élèves.

Mots clés: Apprentissage littéracique, pratiques pédagogiques, connaissance littéracique émergente, interaction en classe.

\section{Il ruolo delle pratiche di insegnamento e della conoscenza iniziale nell'apprendimento delle competenze testuali nello scritto.}

\section{Riassunto}

L'apprendimento del linguaggio scritto è il risultato del contributo incrociato delle competenze iniziali dei bambini e della formazione che ricevono. Gli obiettivi di questo studio sono: (1) valutare le competenze emergenti di literacy dei bambini, sia in termini notazionali sia testuali, all'inizio del terzo anno di scuola dell'infanzia; (2) ottenere un quadro dettagliato delle pratiche formative nella prima formazione al linguaggio scritto nelle nove province spagnole; e (3) determinare la relazione tra questi due fattori e i risultati di apprendimento alla fine del primo anno della formazione primaria.

Nonostante l'identificazione di tre profili ben distinti nelle pratiche formative, $\mathrm{i}$ risultati indicano che lre prestazioni dei bambini nella lingua scritta dipendono più fortemente dal loro livello iniziale di competenza che dalle pratiche dell'insegnante.

Un'osservazione dettagliata delle interazioni d'aula nel contesto di attività specifiche non solo ha permesso di analizzare più attentamente le diverse traiettorie di apprendimento, ma anche di rivelare molteplici aspetti socio-affettivi e attitudinali che sembrano spiegare le differenze nei processi di apprendimento.

Parole chiave: Apprendimento della literacy, pratiche formative, competenze emergenti di literacy, interazioni d'aula. 